\title{
Synthesis, structures, and properties of two new binuclear complexes based on carboxyl-substituted nitronyl nitroxide: $\left[\mathrm{M}_{2}(\mathrm{NITpBA})_{4}\left(\mathrm{H}_{2} \mathrm{O}\right)_{2}\right](\mathrm{M}=\mathrm{Zn}$ and $\mathrm{Cu})$
}

\author{
Jing Chen $^{1,2^{*}}$, You-Juan Zhang ${ }^{1}$, Kun-Tao Huang ${ }^{2}$, Qiang Huang ${ }^{2}$, Jun-Jie Wang ${ }^{1}$ \\ ${ }^{1}$ College of Chemistry and Chemical Engineering, Anyang Normal University, Anyang, China \\ ${ }^{2}$ School of Chemical Engineering and Energy, Zhengzhou University, Zhengzhou, China \\ Email: ${ }^{*}$ chenjinghao2008@163.com
}

Received 13 March 2013; revised 14 April 2013; accepted 23 April 2013

Copyright (C) 2013 Jing Chen et al. This is an open access article distributed under the Creative Commons Attribution License, which permits unrestricted use, distribution, and reproduction in any medium, provided the original work is properly cited.

\begin{abstract}
Two new binuclear complexes, $\left[\mathrm{M}_{2}(\mu \text {-NITpBA })_{4}\left(\mathrm{H}_{2} \mathrm{O}\right)_{2}\right](\mathrm{M}=\mathrm{Zn} 1$ and $\mathrm{Cu} 2)$ [where NIpBA = 2-(4-carboxyl-phenyl)-4,4,5,5-tetramethyl-4,5dihydro-1H-imidazol-1-oxyl-3-oxide], were stylized and characterized. Magnetic susceptibility measurements revealed antiferromagnetic exchange interactions in the two complexes.
\end{abstract}

Keywords: Binuclear Complex; Carboxyl-Substituted; Nitronyl Nitroxide; Antiferromagnetic Exchange

\section{INTRODUCTION}

The past decade has triggered fast-growing interests in nitronyl nitroxide radicals (NITR) as building blocks in the engineering of molecular-based magnet. The reasons are mainly that they are the most stable paramagnetic ligands, even in combination with metal ions where they can also act as bridging ligands [1]. Carboxylate bridges mediate exchange interactions between coordinated metal centres [2,3]. Metal complexes with bridging carboxylates as well as stable organic radical ligands are of considerable interest to the field of molecular magnetism [4]. In an effort to bring together the two areas of research, carboxyl-substituted nitronyl nitroxide, as an important anionic ligand, was deemed favorable for the realization in reactions with metal ions. To the best of our knowledge, to prepare transition metal complexes with nitronyl nitroxide-substituted carboxylate ligands, many investigations on the scope have been recently performed, but the related reports are very scarce $[5,6]$. The only structurally characterized transition metal compounds are 1D-chain systems in which two nitronyl

${ }^{*}$ Corresponding author. nitroxides $\mathrm{NITpBA}^{-}$are coordinated with two metal centers via one NO-group and a monodentate carboxylate group [7,8]. Miller's group even reported on copper (II) compounds with NITpBA ${ }^{-}$assumed to be in a bidentatebridging mode, but did not provide structural information on the related radical-metal compounds [9]. Rentschle's group examined the reaction of NITpBAH with different metal salts, bases, and terminal capping coligands following with various methods but could not isolate any dimeric compounds. Ligand exchange reaction of NITpBAH with copper (II) acetate hydrate, however, leads to the desired system. Recrystallization from hot dimethylsulfoxide/methanol (2:1) leads to formation of small green-blue crystals $\mathrm{Cu}_{2}(\mu-\mathrm{NITpBA})_{4} / \mathrm{H}_{2} \mathrm{O} / \mathrm{dmso}$ [10].

With the purpose of obtaining materials with unusual molecular high nuclearity spin clusters, we were interested in the preparation of carboxylate-bridged metal complexes with pendant organic radical substituents. In this paper, we present the simple synthesis and properties of two new metal-radical binuclear complexes $\left[\mathrm{M}_{2}(\mu\right.$ $\left.\mathrm{NITpBA})_{4}\left(\mathrm{H}_{2} \mathrm{O}\right)_{2}\right](\mathrm{M}=\mathrm{Zn} 1$ and $\mathrm{Cu} 2)$.

\section{EXPERIMENTAL}

\subsection{General}

All reagents used in the synthesis were of analytical grade without further purification. 2-(4-carboxyl-phenyl)4,4,5,5-tetramethyl-4,5-dihydro-1H-imidazol-1-oxyl-3-o xide was prepared by the literature method [11]. Elemental analyses $(\mathrm{C}, \mathrm{H}$, and $\mathrm{N})$ were carried out with a Perkin Elmer $240 \mathrm{C}$ elemental analyzer. IR spectra were recorded from 400 to $4000 \mathrm{~cm}^{-1}$ on an Avatar-360 spectrophotometer using $\mathrm{KBr}$ pellets. Variable-temperature magnetic susceptibilities were measured with a MPMS7SQUID magnetometer at a magnetic field of $2000 \mathrm{G}$. Diamagnetic corrections were made with Pascal's con- 
stants for all constituent atoms.

\subsection{Synthesis of $\left[\mathrm{M}_{2}(\mu \text {-NITpBA })_{4}\left(\mathrm{H}_{2} \mathrm{O}\right)_{2}\right]$ ( $M=\mathrm{Zn} 1$ and $\mathrm{Cu} 2$ )}

\subsection{1. $\left[\mathrm{Zn}_{2}(\mu \text {-NITpBA })_{4}\left(\mathrm{H}_{2} \mathrm{O}\right)_{2}\right] 1$}

NITpBAH $(0.4 \mathrm{mmol}, 0.1076 \mathrm{~g})$ was dissolved in $4 \mathrm{~mL}$ $0.2 \mathrm{M} \mathrm{NaOH}$. The complex 1 was synthesized by the addition of NITpBA ${ }^{-}$and $\mathrm{ZnCl}_{2}(0.2 \mathrm{mmol}, 0.0275 \mathrm{~g})$ to $30 \mathrm{~mL}$ of methanol-water. The mixture was stirred for 2 $\mathrm{h}$ and then filtered. The resulting blue filtrate was kept at room temperature for slow evaporation. After a few days, dark blue crystals of compound 1 suitable for X-ray analysis were obtained. Anal. Found: C, 53.12; H, 5.30; N, 8.61\% Cacl. for C56 H68 N8 O18 Zn2 (1): C, 52.83; $\mathrm{H}, 5.39 ; \mathrm{N}, 8.81 \%$. IR (KBr disk): $1612 \mathrm{~cm}^{-1}\left(v_{\mathrm{as}} \mathrm{COO}^{-}\right)$, $1413 \mathrm{~cm}^{-1}\left(v_{\mathrm{s}} \mathrm{COO}^{-}\right), 1355 \mathrm{~cm}^{-1}(\mathrm{vNO})$.

\subsection{2. $\left[\mathrm{Cu}_{2}(\mu-\mathrm{NITpBA})_{4}\left(\mathrm{H}_{2} \mathrm{O}\right)_{2}\right] 2$}

The complex 2 was prepared in a procedure similar to complex 1 except that $\mathrm{ZnCl}_{2}$ was replaced by $\mathrm{CuCl}_{2}$ Dark blue crystals were obtained expectedly. Anal. Found: C,
52.53; H, 5.16; N, 8.74\% Cacl. for C56 H68 N8 O18 $\mathrm{Cu} 2$ (2): C, 52.98; H, 5.40; N, 8.83\%. IR (KBr disk): $1610 \mathrm{~cm}^{-1}\left(v_{\mathrm{as}} \mathrm{COO}^{-}\right), 1407 \mathrm{~cm}^{-1}\left(v_{\mathrm{s}} \mathrm{COO}^{-}\right), 1350 \mathrm{~cm}^{-1}$ (vNO).

\subsubsection{X-Ray Data Collection and Structure Determination}

$\mathrm{X}$-ray diffraction intensities were collected on a Bruker Smart CCD diffractometer equipped with a graphitemonochromated Mo $\mathrm{K} \alpha$ radiation $(\lambda=0.71073 \AA$ ) by using a $\omega-\varphi$ scan technique at room temperature. Absor ption correction were applied using SADABS program [12]. The structures were solved by direct methods with SHELXS-97 program [13] and refined with SHELXS97[14] by full matrix least-squares technique on $F^{2}$. All the non-hydrogen atoms were refined with anisotropic temperature para-meters. Hydrogen atoms of organic ligands were fixed in ideal positions. The relevant parameters of the crystal structures for complex 1 and 2 are listed in Table 1, and the selected bond lengths and bond angles are given in Tables 2 and 3, respectively.

Table 1. Crystal data and structure refinement for the two complexes 1 and 2.

\begin{tabular}{|c|c|c|}
\hline & 1 & 2 \\
\hline Formula & C56 H68 N8 O18 Zn2 & C56 H68 N8 O18 Cu2 \\
\hline Formula weight & 1271.92 & 1268.26 \\
\hline Crystal system & Monoclinic & Monoclinic \\
\hline Space group & $P 2(1) / c$ & $P 2(1) / c$ \\
\hline \multicolumn{3}{|l|}{ Unit cell dimensions $\left(\AA,^{\circ}\right)$} \\
\hline$a$ & $10.415(2)$ & $10.392(2)$ \\
\hline$b$ & $12.770(3)$ & $12.650(3)$ \\
\hline$c$ & $22.987(5)$ & $23.116(5)$ \\
\hline Volume $\left(\AA^{3}\right), Z$ & $3027.3(11), 2$ & $3010.5(10), 2$ \\
\hline $\mathrm{F}(000)$ & 1328 & 1324 \\
\hline$\theta$ range for data collection $\left({ }^{\circ}\right)$ & 1.83 to 28.40 & 1.84 to 28.40 \\
\hline Limiting indices & $\begin{array}{l}-13 \leq h \leq 13 \\
-15 \leq k \leq 16 \\
-30 \leq l \leq 30\end{array}$ & $\begin{array}{l}-13 \leq h \leq 13 \\
-16 \leq k \leq 16 \\
-30 \leq l \leq 30\end{array}$ \\
\hline Reflections collected & 51,237 & 52,552 \\
\hline Independent reflections & $7419[\mathrm{R}(\mathrm{int})=0.1174]$ & $7505[\mathrm{R}(\mathrm{int})=0.0545]$ \\
\hline Completeness (\%) & 97.9 & 99.3 \\
\hline Final $R$ indices $(I>2 \sigma(I))$ & $R_{1}=0.0771, w R_{2}=0.1852$ & $R_{1}=0.0594, w R_{2}=0.1582$ \\
\hline$R$ indices (all data) & $R_{1}=0.1399, w R_{2}=0.2293$ & $R_{1}=0.0896, w R_{2}=0.1785$ \\
\hline
\end{tabular}


Table 2. Selected bond distances $(\AA)$ and angles ( $\left.{ }^{\circ}\right)$ for the complex 1 .

\begin{tabular}{|c|c|c|c|}
\hline \multicolumn{4}{|c|}{ Bond distances } \\
\hline $\mathrm{Zn}(1)-\mathrm{Zn}(1) \# 1$ & $2.9672(12)$ & $\mathrm{O}(6)-\mathrm{C}(15)$ & $1.254(6)$ \\
\hline $\mathrm{Zn}(1)-\mathrm{O}(1 \mathrm{~W})$ & $1.964(4)$ & $\mathrm{N}(1)-\mathrm{O}(3)$ & $1.275(7)$ \\
\hline $\mathrm{Zn}(1)-\mathrm{O}(2) \# 1$ & $2.025(3)$ & $\mathrm{N}(2)-\mathrm{O}(4)$ & $1.298(16)$ \\
\hline $\mathrm{Zn}(1)-\mathrm{O}(5)$ & $2.025(4)$ & $\mathrm{O}(8)-\mathrm{N}(4)$ & $1.288(5)$ \\
\hline $\mathrm{Zn}(1)-\mathrm{O}(1)$ & $2.030(4)$ & $\mathrm{O}(7)-\mathrm{N}(3)$ & $1.276(6)$ \\
\hline $\mathrm{Zn}(1)-\mathrm{O}(6) \# 1$ & $2.035(4)$ & $\mathrm{N}(4)-\mathrm{C}(22)$ & $1.340(6)$ \\
\hline $\mathrm{O}(1)-\mathrm{C}(1)$ & $1.246(7)$ & $\mathrm{C}(22)-\mathrm{N}(3)$ & $1.354(6)$ \\
\hline $\mathrm{O}(2)-\mathrm{C}(1)$ & $1.249(6)$ & $\mathrm{N}(1)-\mathrm{C}(8)$ & $1.233(8)$ \\
\hline $\mathrm{O}(5)-\mathrm{C}(15)$ & $1.244(6)$ & $\mathrm{C}(8)-\mathrm{N}(2)$ & $1.447(13)$ \\
\hline \multicolumn{4}{|l|}{ Bond angles } \\
\hline $\mathrm{C}(1)-\mathrm{O}(2)-\mathrm{Zn}(1) \# 1$ & $130.0(4)$ & $\mathrm{O}(2) \# 1-\mathrm{Zn}(1)-\mathrm{O}(6) \# 1$ & $90.03(16)$ \\
\hline $\mathrm{C}(15)-\mathrm{O}(6)-\mathrm{Zn}(1) \# 1$ & $132.3(3)$ & $\mathrm{O}(5)-\mathrm{Zn}(1)-\mathrm{O}(6) \# 1$ & $158.99(16)$ \\
\hline $\mathrm{O}(1 \mathrm{~W})-\mathrm{Zn}(1)-\mathrm{O}(2) \# 1$ & $100.2(2)$ & $\mathrm{O}(1)-\mathrm{Zn}(1)-\mathrm{O}(6) \# 1$ & $87.75(17)$ \\
\hline $\mathrm{O}(1 \mathrm{~W})-\mathrm{Zn}(1)-\mathrm{O}(5)$ & $104.5(2)$ & $\mathrm{O}(1 \mathrm{~W})-\mathrm{Zn}(1)-\mathrm{Zn}(1) \# 1$ & $171.23(17)$ \\
\hline $\mathrm{O}(2) \# 1-\mathrm{Zn}(1)-\mathrm{O}(5)$ & $87.60(16)$ & $\mathrm{O}(2) \# 1-\mathrm{Zn}(1)-\mathrm{Zn}(1) \# 1$ & $77.48(12)$ \\
\hline $\mathrm{O}(1 \mathrm{~W})-\mathrm{Zn}(1)-\mathrm{O}(1)$ & $101.2(2)$ & $\mathrm{O}(5)-\mathrm{Zn}(1)-\mathrm{Zn}(1) \# 1$ & 83.94(11) \\
\hline $\mathrm{O}(2) \# 1-\mathrm{Zn}(1)-\mathrm{O}(1)$ & $158.59(17)$ & $\mathrm{O}(1)-\mathrm{Zn}(1)-\mathrm{Zn}(1) \# 1$ & $81.38(13)$ \\
\hline $\mathrm{O}(5)-\mathrm{Zn}(1)-\mathrm{O}(1)$ & $86.91(16)$ & $\mathrm{O}(6) \# 1-\mathrm{Zn}(1)-\mathrm{Zn}(1) \# 1$ & $75.16(11)$ \\
\hline $\mathrm{O}(1 \mathrm{~W})-\mathrm{Zn}(1)-\mathrm{O}(6) \# 1$ & $96.5(2)$ & $\mathrm{C}(1)-\mathrm{O}(1)-\mathrm{Zn}(1)$ & $124.4(4)$ \\
\hline
\end{tabular}

Symmetry codes: $\# 1: \mathrm{x}+1, \mathrm{y}, \mathrm{z}+2$.

Table 3. Selected bond distances $(\AA)$ and angles ( $\left.{ }^{\circ}\right)$ for the complex 2.

\begin{tabular}{|c|c|c|c|}
\hline \multicolumn{2}{|c|}{ Bond distances } & \multirow[b]{2}{*}{$\mathrm{O}(6)-\mathrm{C}(15)$} & \multirow[b]{2}{*}{$1.253(4)$} \\
\hline $\mathrm{Cu}(1)-\mathrm{Cu}(1) \# 1$ & $2.6457(1)$ & & \\
\hline $\mathrm{Cu}(1)-\mathrm{O}(2) \# 1$ & $1.952(2)$ & $\mathrm{O}(5)-\mathrm{C}(15)$ & $1.253(4)$ \\
\hline $\mathrm{Cu}(1)-\mathrm{O}(1)$ & $1.955(3)$ & $\mathrm{O}(3)-\mathrm{N}(1)$ & $1.248(9)$ \\
\hline $\mathrm{Cu}(1)-\mathrm{O}(5)$ & $1.960(2)$ & $\mathrm{N}(2)-\mathrm{O}(4)$ & $1.275(6)$ \\
\hline $\mathrm{Cu}(1)-\mathrm{O}(6) \# 1$ & $1.971(2)$ & $\mathrm{O}(7)-\mathrm{N}(3)$ & $1.279(5)$ \\
\hline $\mathrm{Cu}(1)-\mathrm{O}(1 \mathrm{~W})$ & $2.121(3)$ & $\mathrm{N}(4)-\mathrm{O}(8)$ & $1.271(4)$ \\
\hline $\mathrm{O}(2)-\mathrm{C}(1)$ & $1.255(4)$ & $\mathrm{N}(4)-\mathrm{C}(22)$ & $1.340(5)$ \\
\hline $\mathrm{O}(1)-\mathrm{C}(1)$ & $1.254(5)$ & $\mathrm{C}(22)-\mathrm{N}(3)$ & $1.339(5)$ \\
\hline \multicolumn{4}{|l|}{ Bond angles } \\
\hline $\mathrm{C}(1)-\mathrm{O}(2)-\mathrm{Cu}(1) \# 1$ & $124.1(2)$ & $\mathrm{O}(1)-\mathrm{Cu}(1)-\mathrm{O}(1 \mathrm{~W})$ & $96.67(14)$ \\
\hline $\mathrm{C}(15)-\mathrm{O}(6)-\mathrm{Cu}(1) \# 1$ & $124.8(2)$ & $\mathrm{O}(5)-\mathrm{Cu}(1)-\mathrm{O}(1 \mathrm{~W})$ & $100.95(14)$ \\
\hline $\mathrm{O}(2) \# 1-\mathrm{Cu}(1)-\mathrm{O}(1)$ & $167.82(12)$ & $\mathrm{O}(6) \# 1-\mathrm{Cu}(1)-\mathrm{O}(1 \mathrm{~W})$ & $90.97(14)$ \\
\hline $\mathrm{O}(2) \# 1-\mathrm{Cu}(1)-\mathrm{O}(5)$ & $88.99(12)$ & $\mathrm{O}(2) \# 1-\mathrm{Cu}(1)-\mathrm{Cu}(1) \# 1$ & $83.00(9)$ \\
\hline $\mathrm{O}(1)-\mathrm{Cu}(1)-\mathrm{O}(5)$ & $88.35(12)$ & $\mathrm{O}(1)-\mathrm{Cu}(1)-\mathrm{Cu}(1) \# 1$ & $84.96(9)$ \\
\hline $\mathrm{O}(2) \# 1-\mathrm{Cu}(1)-\mathrm{O}(6) \# 1$ & $90.66(12)$ & $\mathrm{O}(5)-\mathrm{Cu}(1)-\mathrm{Cu}(1) \# 1$ & $86.15(8)$ \\
\hline $\mathrm{O}(1)-\mathrm{Cu}(1)-\mathrm{O}(6) \# 1$ & $89.49(12)$ & $\mathrm{O}(6) \# 1-\mathrm{Cu}(1)-\mathrm{Cu}(1) \# 1$ & $81.96(8)$ \\
\hline $\mathrm{O}(5)-\mathrm{Cu}(1)-\mathrm{O}(6) \# 1$ & $168.05(11)$ & $\mathrm{O}(1 \mathrm{~W})-\mathrm{Cu}(1)-\mathrm{Cu}(1) \# 1$ & $172.74(13)$ \\
\hline $\mathrm{O}(2) \# 1-\mathrm{Cu}(1)-\mathrm{O}(1 \mathrm{~W})$ & $95.51(14)$ & & \\
\hline
\end{tabular}

Symmetry codes: $\# 1: \mathrm{x}, \mathrm{y}+2, \mathrm{z}$. 


\section{RESULTS AND DISCUSSION}

\subsection{Description of Crystal Structures}

Crystal analysis show that compounds 1 and 2 are iso structural. They crystallize in the monoclinic system, $P 2_{1} / c$ (No.14) space group, which are different from that lecture [10] (triclinic system, space group $P_{1}$ ). The asymmetric unit consists of one-half of a dimeric metal ion bridged by O-carboxyl from four nitronyl nitroxide. The two halves are related to each other through a center of inversion located in the middle of the M-M axis. The coordination geometry of $\mathrm{Zn}$ (II) and $\mathrm{Cu}$ (II) lies at the center of the distorted octahedral geometry formed by five oxygen atoms, which come from four equivalent nitroxide ligand, one water molecule, and the M-M distances of the neighboring metal atoms is $[\mathrm{Zn} 1-\mathrm{Zn} 1(\mathrm{~A})$ $2.9672 \AA$ and $\mathrm{Cu} 1-\mathrm{Cu} 1$ (A) $2.6457 \AA$ ], which is rather short and may be regarded as the normal M-M bonding range $[15,16]$. Their molecular structures are depicted in

Figures 1 and 2, respectively.

In complex 1, the $\mathrm{C} 1-\mathrm{O} 1$ and $\mathrm{C} 1-\mathrm{O} 2$ bonds from the same carboxylate group are equal to 1.246 and $1.249 \AA$, respectively, whereas the distance of $\mathrm{C} 15-\mathrm{O} 5$ and $\mathrm{C} 15-$ $\mathrm{O} 6$ are of 1.244 and $1.254 \AA$, respectively. The $\mathrm{Ph}-\mathrm{COO}$ bonds of $1.5093 \AA$ are close to that reported in the literature [11]. The $\mathrm{C}-\mathrm{C}$ bond lengths of the phenyl rings show no alternation and are located in the aromatic region ranging from 1.361 to $1.394 \AA$. The $\mathrm{Zn}-\mathrm{O}_{\text {water }}$ distance of $1.964 \AA$ is shorter than that of $\mathrm{Zn}-\mathrm{O}$ whose oxygen atoms are from $\mathrm{Ph}_{-} \mathrm{COO}^{-}$. Four oxygen atoms from $\mathrm{Ph}-\mathrm{COO}^{-}$of the nitroxide ligand compose the equatorial plane. The O5-Zn1-O6A angle in the equatorial plane is $158.99^{\circ}$, and the O1-Zn1-O2A angle is equal to $158.59^{\circ}$. The O1W-Zn1-Zn1A angle in the axial position is $171.23^{\circ}$. The Zn (II) center is displaced by $0.324 \AA$ from the basal O4-plane toward the axial oxygen atom from $\mathrm{H}_{2} \mathrm{O}$. The fragment O4-N2-C8-N1-O3 is non-planar, and it forms a dihedral angle of $65.1^{\circ}$ with the plane of the phenyl ring (C6-C5-C4). Conversely, the fragment O8N4-C22-N3-O7 is nearly planar and forms a dihedral angle of $35.1^{\circ}$ with the plane of the phenyl ring (C19C18-C20). The IR spectrum shows the N-O stretching vibration of the NITpBA at $1355 \mathrm{~cm}^{-1}$ as well as the antisymmetric $v_{\mathrm{as}} \mathrm{COO}^{-}$and the symmetric $v_{\mathrm{s}} \mathrm{COO}^{-}$ stretching mode of the caroxyl group at 1612 and 1413 $\mathrm{cm}^{-1}$, respectively, in accordance with a bidentatebridging mode $[10,17,18]$.

In complex 2 , the $\mathrm{Cu}-\mathrm{Cu} 1 \mathrm{~A}$ distance is $2.6457 \AA$, which is a typical value for dimeric copper (II) carboxylate adducts $[19,20]$. The $\mathrm{Cu}-\mathrm{O}_{\text {water }}$ distance of $2.121 \AA$ is longer than that of $\mathrm{Cu}-\mathrm{O}$ whose oxygen atoms come from $\mathrm{Ph}-\mathrm{COO}^{-}$. The $\mathrm{Cu}$ (II) core is displaced by $0.205 \AA$ from the basal O4-plane toward the axial oxygen atom of the solvent. Mean deviation from base O4-plan

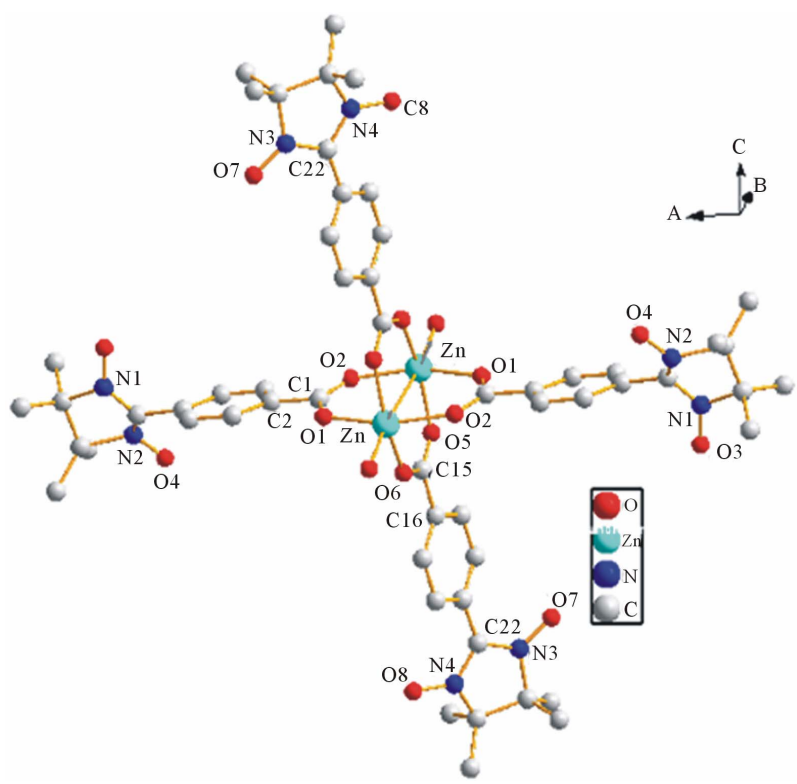

Figure 1. View of the moiety of the complex 1

$\left[\mathrm{Zn}_{2}(\mathrm{NITpBA})_{4}\left(\mathrm{H}_{2} \mathrm{O}\right)_{2}\right]$. All hydrogen atoms are omitted for clarity.

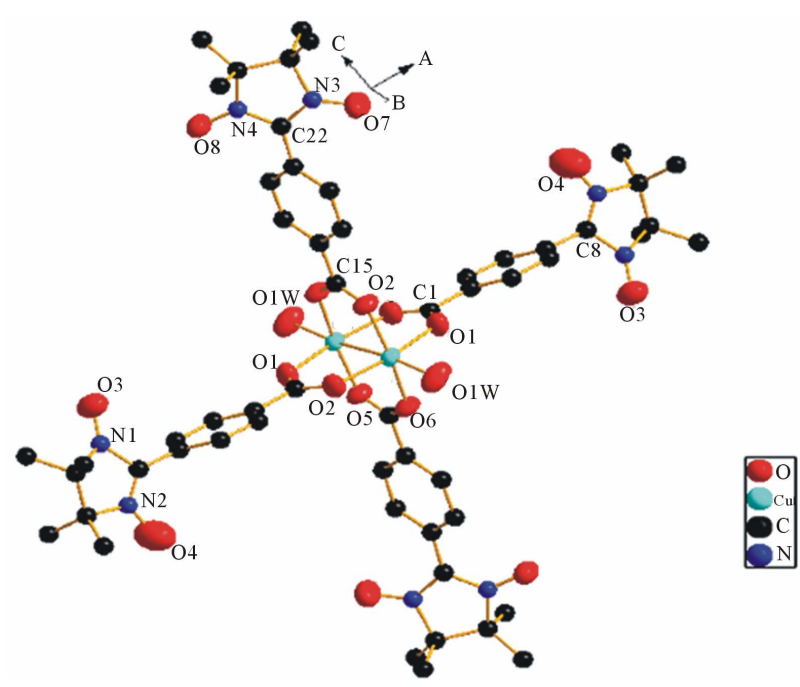

Figure 2. View of the moiety of the complex 2

$\left[\mathrm{Cu} 2(\mathrm{NITpBA})_{4}\left(\mathrm{H}_{2} \mathrm{O}\right)_{2}\right]$. All hydrogen atoms are omitted for clarity.

is $0.0009 \AA$. The fragment O4-N2-C8-N1-O3 is nonplanar, where the mean deviation from the plane is $0.0676 \AA$, and forms a dihedral angle of $86.1^{\circ}$ with the plane of the phenyl ring (C4-C5-C6). The fragment O8-N4-C22-N3-O7 is nearly planar, and the plane for $\mathrm{ms}$ a dihedral angle of $36.4^{\circ}$ with the phenyl ring (C19-C18-C20). The product shows IR absorptions at 13 50,1407 and $1610 \mathrm{~cm}^{-1}$, respectively.

\subsection{Magnetic Properties}

We have then examined the temperature dependences of 
$\chi_{\mathrm{M}} \mathrm{T}$ and $\chi_{\mathrm{M}}$ for complex 1 and 2 in order to analyze the exchange coupling in this six-spin system. Temperature dependences of the molar magnetic susceptibility for two complexes were measured in a temperature range of $2 \mathrm{~K}$ to $300 \mathrm{~K}$ at a magnetic field of $2000 \mathrm{G}$. The results are given in Figures $\mathbf{3}$ and $\mathbf{4}$, respectively.

For complex 1, the $\chi_{\mathrm{M}} \mathrm{T}$ at room temperature has a value of $1.535 \mathrm{emu} \cdot \mathrm{K} \cdot \mathrm{mol}^{-1}$, which is close to the expected value for uncoupled spins of $S=4 / 2$ (1.5 emu. $\mathrm{K} \cdot \mathrm{mol}^{-1}$ ) for two zinc centers and four nitronyl nitroxide radical-ligands. It was regarded as a tetra-radical system to evaluate the exchange coupling constants. The $\chi_{M} T$ value decreases slowly and reaches $1.43 \mathrm{emu} \cdot \mathrm{K} \cdot \mathrm{mol}^{-1}$ at $100 \mathrm{~K}$ as the temperature is lowered, and subsequently decreases rapidly during further lowering of temperature. Based on the structural results, it undergoes a major magnetic interaction in the present system, in which the exchange interaction of NITpBA radicals through $\mathrm{Zn}$ (II) core exists [21]. The result indicates that a weak antiferromagnetic exchange interaction is predominant, which is agreement with literatures [22,23].

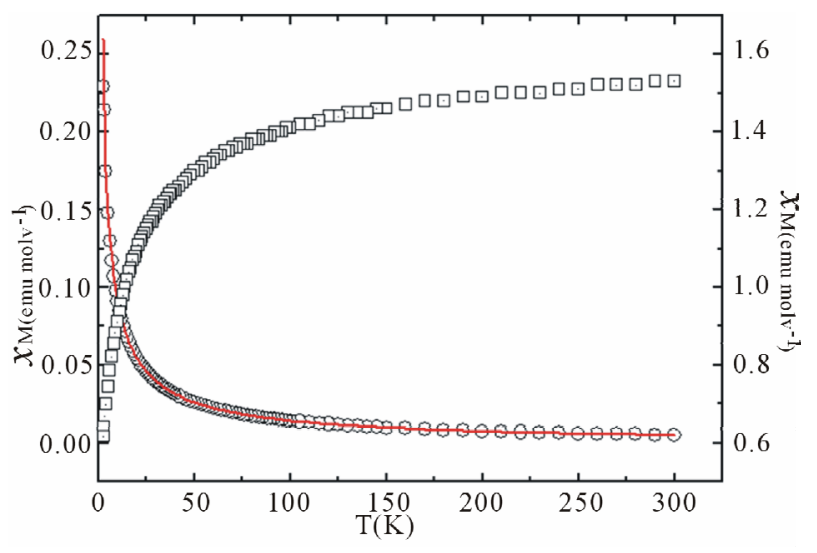

Figure 3. Temperature dependece of $\chi \mathrm{M}(\circ)$ and $\chi \mathrm{MT}(\square)$ vs T for the complex 1

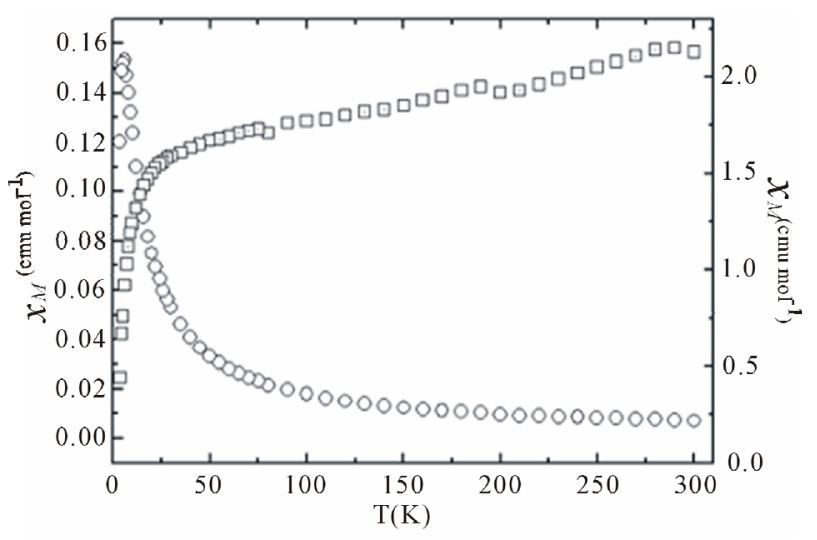

Figure 4. Temperature dependece of $\chi \mathrm{M}(\circ)$ and $\chi \mathrm{MT}(\square)$ vs $\mathrm{T}$ for the complex 2
For complex 2 , the $\chi_{\mathrm{M}} \mathrm{T}$ value at room temperature is $2.14 \mathrm{emu} \cdot \mathrm{K} \cdot \mathrm{mol}^{-1}$, which is significantly lower than that of the expected value for six uncoupled spins of $S=1 / 2$ $\left(2.25 \mathrm{emu} \cdot \mathrm{K} \cdot \mathrm{mol}^{-1}\right)$ for two copper centers and four nitronyl nitroxide. The result indicates that a strong antiferromagnetic exchange interaction is predominant. The result is in accord with those reported [10,24].

\section{CONCLUSION}

Two new binuclear complexes formulae of $\left[\mathrm{M}_{2}(\mu-\right.$ $\mathrm{NITpBA})_{4}\left(\mathrm{H}_{2} \mathrm{O}\right)_{2}$ ] $(\mathrm{M}=\mathrm{Zn} 1$ and $\mathrm{Cu} 2)$ [where NITpBA =2-(4-carboxyl-phenyl)-4,4,5,5-tetramethyl-4,5-dihydro1H-imidazol-1-oxyl-3-oxide)] were synthesized and structurally characterized. The simple procedure of the NITpBAH with metal chloride yielded dimeric complexes 1 and 2. The temperature dependences of the magnetic susceptibility show dominant itram-olecular antiferromagnetic exchange interaction in complexes 1 and 2 . According to the result of the complex 1, it demonstrates that the magnitude of the intramolecular magnetic exchange has little relationship with the crystal system and space group.

\section{ACKNOWLEDGEMENTS}

This work was supported by the National Natural Science Foundation of China (No. 21071006), the Natural Science Foundation of Henan Province (No. 102102 210457) and the Natural Science Foundation of the Henan Higher Education Institutions of China (No. 2010 B150001).

\section{REFERENCES}

[1] Caneschi, A., Gatteschi, D., Sessoli, R. and Rey, P. (1989) Toward molecular magnets: The metal-radical approach. Accounts of Chemical Research, 22, 392-398. doi:10.1021/ar00167a004

[2] Boskovic, C., Pink, M., Huffman, J.C., Hendrickson, D.N. and Christou, G. (2001) Single-molecule magnets: Ligand-induced core distortion and multiple Jahn-Teller isomerism in $\left[\mathrm{Mn} 12 \mathrm{O} 12(\mathrm{O} 2 \mathrm{CMe}) 8(\mathrm{O} 2 \mathrm{PPh} 2) 8\left(\mathrm{H}_{2} \mathrm{O}\right)_{4}\right]$. Journal of the American Chemical Society, 123, 99149915. doi:10.1021/ja016341+

[3] Aubin, S.M.J., Sun, Z., Eppley, H.J., Rumberger, E.M., Guzei, I.A., Folting, K., Gantzel, P.K., Rheingold, A.L., Christou, G. and Hendrickson, D.N. (2001) Single-molecule magnets: Jahn-Teller isomerism and the origin of two magnetization relaxation processes in $\mathrm{Mn} 12 \mathrm{com}-$ plexes. Inorganic Chemistry, 40, 2127-2146. doi:10.1021/ic000911+

[4] Kahn, O. (1993) Molecular magnetism. VCH, Weinheim.

[5] Inoue, K. and Iwamura, H. (1993) Magnetic properties of the crystals of $p$-(1-oxyl-3-oxido-4,4,5,5-tetramethyl-2-imidazolin-2-yl)benzoic acid and its alkali metal salts. 
Chemical Physics Letters, 207, 551-554. doi:10.1016/0009-2614(93)89046-K

[6] Ballester, G., Coronado, E., Galán-Mascarós, J.R., Giménez-Saiz, C., Nuez, A. and Romero, F.M. (2001) A new approach for the synthesis of magnetic materials based on nitroxide free radicals and inorganic coordination polymers. Polyhedron, 20, 1659-1662.

[7] Schiødt, N.C., Fabrizi de Biani, F., Caneschi, A. and Gatteschi, D. (1996) Structure and magnetism of nickel (II) and manganese (II) complexes of a nitronyl nitroxide carboxylic acid. Inorganica Chimica Acta, 248, 139-146. doi:10.1016/0020-1693(95)04996-7

[8] Zhao, Q.H., Li, L.C., Jiang, Z.H., Liao, D.Z., Yan, S.P. and Fang, R.B. (2004) Synthesis and structure of a novel one-dimensional chain compound formed by copper (II) and nitronyl nitroxide radical. Journal of Chemical Crystallography, 34, 191-193. doi:10.1023/B:JOCC.0000021563.00957.85

[9] Del Sesto, R.E., Arif, A.M. and Miller, J.S. (2000) Copper (II) benzoate nitroxide dimers and chains: Structure and magnetic studies. Inorganic Chemistry, 39, 48944902. doi: $10.1021 /$ ic 0007106

[10] Schatzschneider, U., Weyhermüller, T. and Rentschler, E. (2002) Copper complexes with mono- and bidentatebridging nitronyl nitroxide-substituted benzoate ligands. Inorganica Chimica Acta, 337, 122-130. doi:10.1016/S0020-1693(02)01103-9

[11] Bätz, C., Amann, P., Deiseroth, H.J. and Dulog, L. (1994) Die oxidation zweier neuer 1,3-dihydroxyimidazolidinedarstellung und Struktur von Nitronylnitroxid-Radikalen. Liebigs Annalen der Chemie, 7, 739-740. doi:10.1002/jlac.199419940715

[12] Sheldrick, G.M. (1997) SHELXS97, program for the solution of crystal structure. University of Göttingen, Göttingen.

[13] Sheldrick, G.M. (1997) SHELXS97, program for the refinement of crystal structure. University of Göttingen, Göttingen.

[14] Sheldrick, G.M. (1996) SADABS. University of Göttingen, Göttingen.

[15] Ohmura, T., Mori, W., Takei, T., Ikeda, T. and Maeda, A. (2005) Structure and magnetic behaviour of mononuclear and dinuclear $\mathrm{Cu}$ (II)/Zn (II) monocarboxylate-pyridine derivatives studied by crystal engineering. Materials
Science-Poland, 23, 729-732.

[16] Chui, S.S.Y.S., Lo, M.F., Chammant, J.P.H., Orpen, A.G. and Williams, I.D. (1999) A chemically functionalizable nanoporous material $\left[\mathrm{Cu}_{3}(\mathrm{TMA})_{2}\left(\mathrm{H}_{2} \mathrm{O}\right)_{3}\right]_{\mathrm{n}}$. Science, 283, 1148-1150. doi:10.1126/science.283.5405.1148

[17] Deacon, G.B. and Phillips, R.J. (1980) Relationships between the carbon-oxygen stretching frequencies of carboxylato complexes and the type of carboxylate coordination. Coordination Chemistry Reviews, 33, 227-250. doi:10.1016/S0010-8545(00)80455-5

[18] Alcock, N.W., Tracy, V.M. and Waddington, T.C. (1976) Acetates and acetato-complexes. Part 2. Spectroscopic studies. Journal of the Chemical Society, Dalton Transactions, 21, 2243-2245. doi:10.1039/dt9760002243

[19] Lewis, J., Lin, Y., Royston, L. and Thompson, R. (1965) The chemistry of polynuclear compounds. Part III. Magnetic properties of some carboxylic acid derivatives of copper (II). Journal of the Chemical Society, 17, 64646477. doi:10.1039/jr9650006464

[20] Lippard, S.J. and Doedens, R.J. (2007) Structure and metal-metal interactions in copper (II) carboxylate complexes. Progress in Inorganic Chemistry, 21, 209-231.

[21] Castro, I., Sletten, J., Calatayud, M.L., JuIve, M., Cano, J., Lloret, F. and Caneschi, A. (1995) Synthesis and magnetic properties of a tetranuclear copper (II) complex with a mu.-1,2,3,4-squarato coordination mode. Crystal structure of $u$-1,2,3,4-squarato)tetrakis [(tris(2-aminoethyl)amine)copper (II)] perchlorate. Inorganic Chemistry, 34, 4903-4909. doi:10.1021/ic00123a027

[22] Gao, D.Z., Zhao, W.W., Chen, Y.W. and Sun, Y.Q. (2009) Synthesis, crystal structure and magnetic behavior of a new $\mathrm{Zn}$ (II) nitronyl nitroxide complex $\left[\mathrm{Zn}\left(\mathrm{NIT}_{3} \mathrm{Py}\right)_{2} \mathrm{Cl}_{2}\right]$. Chinese Journal of Inorganic Chemistry, 25, 738-741.

[23] Wang, S.P., Gao, D.Z., Liao, D.Z., Jiang. Z.H. and Yan, S.P. (2006) Two novel diamagnetic-metal coordination polymers of nitronyl nitroxide radical incorporating isophthalate bridges. Transition Metal Chemistry, 31, 214219. doi:10.1007/s11243-005-6396-x

[24] Chen, J., Liao, D.Z., Jiang, Z.H. and Yan, S.P. (2005) A new heterospin complex from oxamide-bridged $\mathrm{Cu}$ (II) binuclear units and carboxyl-phenyl-substituted nitronyl nitroxide. Inorganic Chemistry Communications, 8, 564567. doi:10.1016/i.inoche.2005.02.015 


\section{APPENDIX A. SUPPLEMENTARY DATA}

Detailed crystallographic data in CIF format for the title complex are available from Cambridge Crystallographic Data Center (CCDC ID: 876210 and 876209). CIF deposits may now be made using our new online service: https://www.ccdc.cam.ac.uk/services/structure_deposit. 